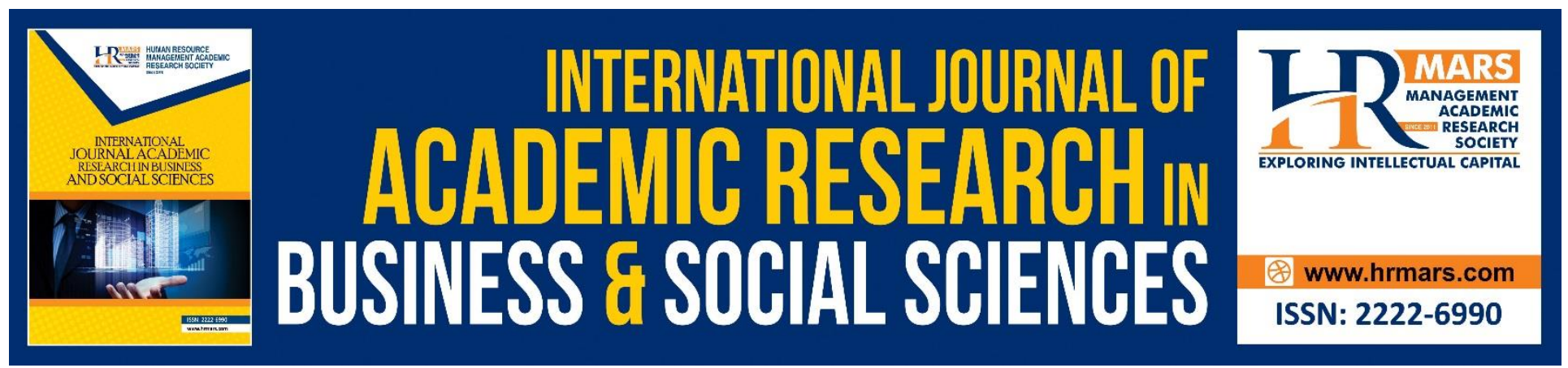

\title{
The Effects of Perceived Organizational Support on the Turnover Intention: A Case Study of Textile Sector
}

Muhammad Zubair Shafique, Muhammad Zia ud Din, Muhammad Tahir Nadeem, Mohy ud Din, Rub Nawaz

To Link this Article: http://dx.doi.org/10.6007/IJARBSS/v8-i9/4637

DOI: $\quad 10.6007 /$ IJARBSS/v8-i9/4637

Received: 02 August 2018, Revised: 29 August 2018, Accepted: 16 Sept 2018

Published Online: 11 October 2018

In-Text Citation: (Shafique, Din, Nadeem, Din, \& Nawaz, 2018)

To Cite this Article: Shafique, M. Z., Din, M. Z. ud, Nadeem, M. T., Din, M. ud, \& Nawaz, R. (2018). The Effects of Perceived Organizational Support on the Turnover Intention: A Case Study of Textile Sector. International Journal of Academic Research in Business and Social Sciences, 8(9), 547-558.

Copyright: (C) 2018 The Author(s)

Published by Human Resource Management Academic Research Society (www.hrmars.com)

This article is published under the Creative Commons Attribution (CC BY 4.0) license. Anyone may reproduce, distribute, translate and create derivative works of this article (for both commercial and non-commercial purposes), subject to full attribution to the original publication and authors. The full terms of this license may be seen

at: http://creativecommons.org/licences/by/4.0/legalcode

Vol. 8, No. 9, September 2018, Pg. 547 - 558

http://hrmars.com/index.php/pages/detail/IJARBSS

JOURNAL HOMEPAGE

Full Terms \& Conditions of access and use can be found at http://hrmars.com/index.php/pages/detail/publication-ethics 


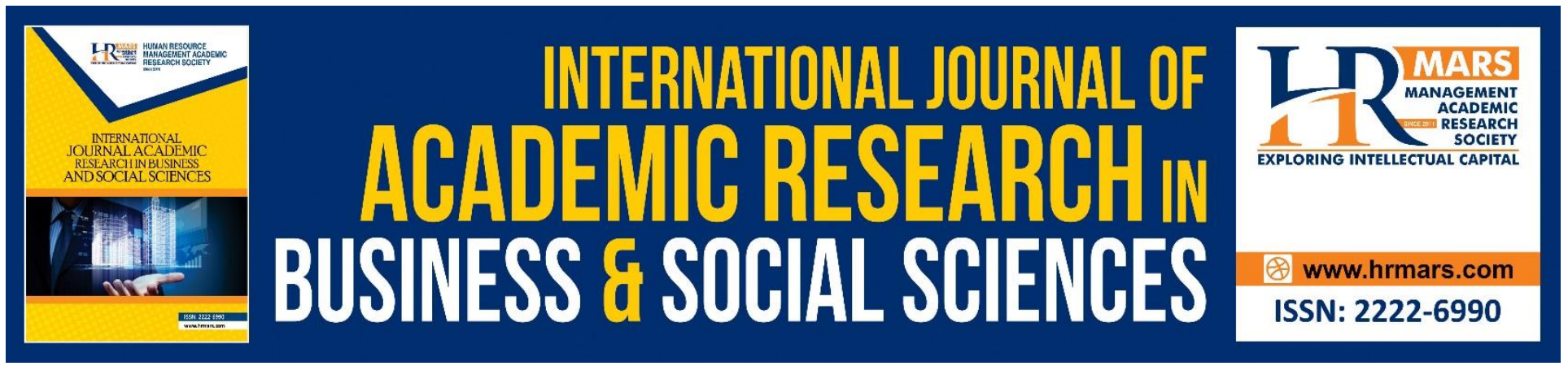

\title{
The Effects of Perceived Organizational Support on the Turnover Intention: A Case Study of Textile Sector
}

\author{
Muhammad Zubair Shafique \\ MS Scholar (Department Public Administration), Government College University, Faisalabad \\ Pakistan
}

Email: zubairshafique5@gmail.com

Muhammad Zia ud Din

Lecturer (Department Public Administration), Government College University, Faisalabad Pakistan

Email: zeeyah4@hotmail.com

\section{Muhammad Tahir Nadeem}

MS Scholar (Department Public Administration), Government College University, Faisalabad Pakistan

Email: tahirn82447@gmail.com

Mohy ud Din

MS Scholar (Department Public Administration), Government College University, Faisalabad Pakistan

Email: mohy092@gmail.com

\section{Rub Nawaz}

MS Scholar (Department Public Administration), Government College University, Faisalabad Pakistan

Email: rub.nawaz10805@gmail.com

\section{ABSTRACT}

The study tried to analyze the relationship between perceived organizational support and turnover intention along with psychological contract breach. Researchers used SPSS version 21.0 to examine the data. The participants of this research are middle and top-level managers and their subordinates from the textile sector of Faisalabad city. Data was distributed among 215 participants and collect from 192. This research was tested at 0.05 to generate the hypothesis. The results of this 
INTERNATIONAL JOURNAL OF ACADEMIC RESEARCH IN BUSINESS AND SOCIAL SCIENCES Vol. 8, No. 9, Sept. 2018, E-ISSN: 2222-6990 @ 2018 HRMARS

study showed the positive relationship between turnover intention and perceived organizational support. The results also showed the positive relationship that psychological contract breach moderates between turnover intention and perceived organizational support. Moreover, this research includes recommendations, conclusions and future research.

Keywords: Turnover Intention (TI), Perceived Organizational Support (POS), Psychological Contract Breach (PCB), Job Satisfaction.

\section{INTRODUCTION}

\section{Background Information}

Turnover intention is an employee psychological response where he has thought about goodbye the company for another (Aliyu \& Nyadzayo, 2018). Employee turnover is a significant area of study of human resource management, after a thousand publications and research(Memon, Sallaeh, Baharom, Md Nordin, \& Ting, 2017). It is very important for employers to overcome on turnover intention because companies invest on workers due to retaining training, induction, and developing (Ongori, 2007). Turnover intention is an important matter for industries in the relationship with holding human capital to keep up the association's intensity for effective talent management(W. Kim \& Hyun, 2017). Employees who feel uncomfortable for a job they leave organization it means organizational climate has played a very important role in turnover intention(Riaz et al., 2017). A high turnover rate brings down employee confidence and it is very costly(Chen, Kim, Liu, Wang, \& Zhao, 2018). Furthermore, firms fear to lose exceptionally talented and competent worker, while workers who stay within the organization may essentially be there that they have been not able to protect the work somewhere else(Tanova \& Holtom, 2008).

Turnover is a significant problem for the textile sector of Pakistan due to the simplicity of job shifting, job opportunity, and demand for trained employees(Hussain \& Asif, 2012). Turnover of competent and skilled employees is a huge loss for the firm(Ashar, Ghafoor, Munir, \& Hafeez, 2013). Many researchers have taken the attention of turnover at the workplace(Richer, Blanchard, \& Vallerand, 2002). Managers and researchers take into account turnover a problem due to costs related to it(Noor \& Maad, 2009). There are many reasons behind the turnover which researchers and managers are trying to find out(Rahman, Naqvi, \& Ramay, 2008). Due to turnover intention organizational goals and objectives are affecting(Qureshi et al., 2013). Turnover is an important problem primarily within the area of Human Resource Management, This is often concentrating on market clearing stage on the prices connected with high turnover(lqbal, Ehsan, Rizwan, \& Noreen, 2014). Nowadays Managers are deeply evaluating the management problems that contribute to discontent and turnover intention eventually impacts on organizational objectives and goals (Qureshi et al., 2013).

\section{Problem Statement}

In the textile sector of Pakistan as a problem, employee turnover exists particularly on the low level but middle-level employees are also sometimes quit the job. Due to load shedding the textile sector is facing issues and bearing high prices, however, the turnover rate is also the inevitable price for the business(Makhdoom, 2018). Moreover, the inaccessibility of gas, competition and the higher rate of raw material have fallen these beneficial textile industries causes turnover, cutbacks, and 
INTERNATIONAL JOURNAL OF ACADEMIC RESEARCH IN BUSINESS AND SOCIAL SCIENCES

Vol. 8, No. 9, Sept. 2018, E-ISSN: 2222-6990 (C) 2018 HRMARS

shutdowns(Farooqui \& Ahmed, 2013). If we deeply follow into more detail then we found that executives make strategies for their own particular benefits and sometimes employees are neglected(Nawaz \& Siraji, 2009).

\section{RESEARCH QUESTIONS}

Following the above problem statement, these questions can be raised.

1-What is the impact of turnover intention on perceived organizational support in the textile sector of Pakistan?

2-What is the impact of turnover intention on psychological contract breach in the textile sector of Pakistan?

\section{STUDY OF THE OBJECTIVE}

The study of the objective is.

1. To examine the impact of turnover intention on perceived organizational support.

2. To explore the impact of turnover intention psychological contract breach.

\section{STATEMENT OF PURPOSE}

The present study targeted to investigate the moderating impact of psychological contract breach on turnover intention and perceived organizational support in the textile sector.

\section{SIGNIFICANCE OF THE STUDY}

The study is vital to investigate and additional insights into the impact on POS and PCB near the TI. Likewise, to what degree do PCB in the relationships and perceived organizational influence the employees turnover intention. It contributes insights on employee intention for leaving by the individual perceived turnover development examines had been led in numerous areas.

\section{LITERATURE REVIEW}

\section{Turnover Intention}

According to the theory of human capital, gaining the human capital has a significant impact towards the turnover intention(Manchester, 2010). At the point when workers leave a textile sector, that industry may encounter extra expenses not just bear the loss of trained employees but in addition from the bear of cost spent on employees, so the consumption identified with training and development and identified with enhancing efficiency (Lee \& Ha-Brookshire, 2017). Moreover due to turnover organizations may lose the social and human capital and may adversely impact on the performance of the organization(Nie, Lämsä, \& Pučètaitė, 2018). Longitudinal research presented that dissatisfaction of job leads toward the better job find and create the turnover(Jaramillo, Mulki, \& Solomon, 2006). Workforces with turnover intentions are further expected to vary their desires to finding and relating to managers hence less time energy and invest in existing work(Yuan, Yu, Li, \& Ning, 2014). According to the theory of longitudinal that employees who did not change the organization and motivated into a new profession had higher levels of dissatisfaction of work than workers who did change their organization(Egan, Yang, \& Bartlett, 2004). The workers who meet and exceed goals decreasing the turnover rate and make a remarkable influence on the overall 
INTERNATIONAL JOURNAL OF ACADEMIC RESEARCH IN BUSINESS AND SOCIAL SCIENCES Vol. 8, No. 9, Sept. 2018, E-ISSN: 2222-6990 @ 2018 HRMARS

organization's outcome(Gyensare, Anku-Tsede, Sanda, \& Okpoti, 2016). Turnover intention to leave is processed happen the approach of stress-and-change-related behaviors and distinct variances. Such as social relationship and culture of organization focus on the issues, for instance, organizational factor(Khoo, Chan, Leong, Ng, \& Siam, 2017). TI can be influenced by different components. One of the components that the workers have the aim to leave their existing firm is on account of the firm can't satisfy their desire contrast with what the new firm can offer them(Chan, Chok, Lae, Lam, \& Lee, 2017). According to the psychological theory of employee turnover, the employee quit the job because he thinks that the new job comes more satisfaction on the account of the previous job (Poon, 2004).

\section{Perceived Organizational Support}

It is believed that the growth of POS is stimulated by workers trend to allocate the firm manlike characteristics(Rhoades \& Eisenberger, 2002). Many researchers have examined workers believe that firm appreciate their input and give attention to the comfort of employees(Eisenberger, Huntington, Hutchison, \& Sowa, 1986). According to the theory of social exchange where occupation is observed as the job of determination and reliability by the worker for allowances or perks and shared interests from the company(Kurtessis et al., 2015). Perceived organizational support is linked with workers emotional comfort, their encouraging coordination concerning their job and firm, and behaviours useful to the organization(K. Y. Kim, Eisenberger, \& Baik, 2016). Perceived organizational support may consider as a resource for the organization that accomplishes the emotional desires of workers like self-confidence, endorsement, and association(Gupta, Agarwal, \& Khatri, 2016). Numerous scholars have recommended the conceivable look of perceived organizational support in the growth of workers' activity(Caesens, Marique, Hanin, \& Stinglhamber, 2016). Perceived organizational support formed by cause of work environments and human resource practices offer the formation of positive behaviour and attitude of the employee. Rational management, managerial provision, rewards and promising work conditions exhibited a strong affiliation with perceived organizational support (Colakoglu, Culha, \& Atay, 2010).

\section{Psychological Contract Breach}

It means the firm has unsuccessful to attain its responsibilities or promises towards employees(Robinson \& Rousseau, 1994). Trust of Employee is established on the view that organizations fulfill the promise and an employee offered commitment in exchange for organization promise(Kickul \& Lester, 2001). Many studies showed the adverse influence of PCB on employee work behaviour and attitude concerning their job(Lester, Turnley, Bloodgood, \& Bolino, 2002). Psychological contract has a breach when the organization did not fulfill their promise. The psychological contract can contain the beliefs of employee and expectancies, it is not essential that the organization share these expectations in the exchange relationship(Johnson \& O'Leary-Kelly, 2003). It can happen due to the nonexistence of an actual breach(Robinson, 1996). Opinions of the employee on breach have adverse outcomes for the company, for instance, poor performance, citizenship behavior, lowered obligation and fulfillment along with actual turnover(Gakovic \& Tetrick, 2003). 


\section{THEORETICAL FRAMEWORK}

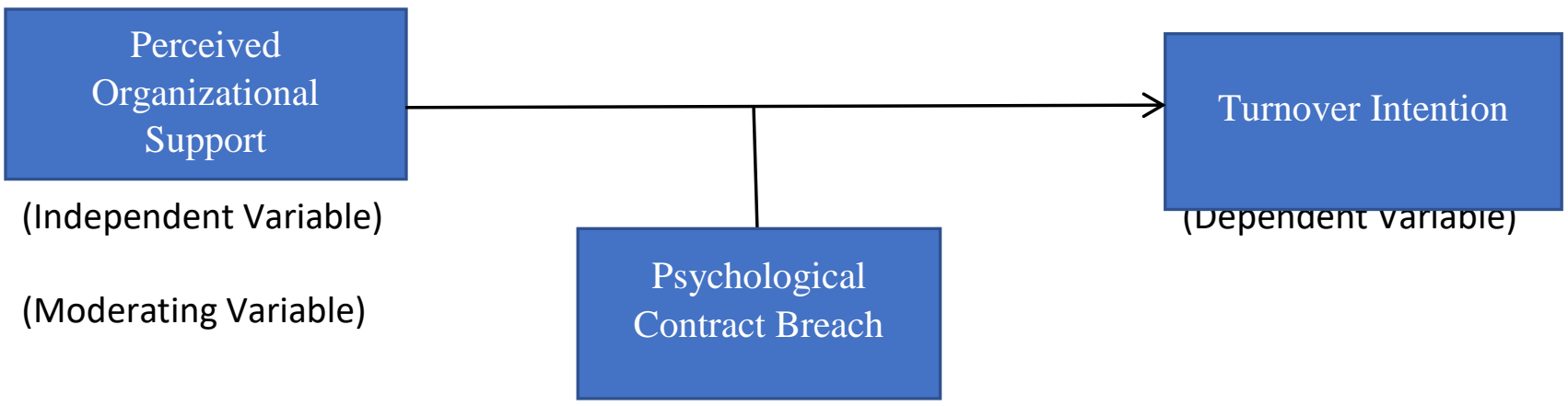

\section{HYPOTHESIS}

To follow the research objective these hypotheses can be generated.

$\mathrm{H} 1$ : There is a positive relationship between Turnover Intention and Perceived Organizational Support.

H2: There is a positive relationship between Perceived Organizational Support and Psychological Contract Breach.

H3: Psychological Contract Breach moderates the relationship between Turnover Intention and Perceived Organizational Support.

\section{PARTICIPANTS AND PROCEDURE}

The employees working at the middle and top level in the textile sector of the Faisalabad city were the participants of the study. The study was conducted from different textile mills in Faisalabad. The survey-based questionnaire was distributed among participants for data collection. For the better understanding of participants, every question is defined before distributing the questionnaire. Overall 215 survey based questionnaires were randomly circulated among the staffs and 192 are completely and fairly returned with the response rate of $89.3 \%$.

\section{MEASURES}

The 5-point scale was utilized to gauge the items ranging on 1=strongly disagree to $5=$ strongly agree.

\section{Turnover Intention}

Turnover intention was rated via using the three items and developed by(Cummann, Fichman, Jenkins, \& Klesh, 1979).

\section{Psychological Contract Breach}

PCB was rated by using the five items and scale developed by(Rousseau, 1995).

\section{Perceived Organizational Support}

It was also rated by using five items and scale adopted from(Eisenberger et al., 1986). 
INTERNATIONAL JOURNAL OF ACADEMIC RESEARCH IN BUSINESS AND SOCIAL SCIENCES

Vol. 8, No. 9, Sept. 2018, E-ISSN: 2222-6990 @ 2018 HRMARS

\section{Demographics}

\begin{tabular}{llll}
\hline Variable & Scale & Frequency & Percentage \\
\hline Age & $18-25$ & 78 & 40.7 \\
& $26-35$ & 69 & 35.9 \\
& $36-45$ & 31 & 16.1 \\
& $46-50$ & 6 & 3.1 \\
& $51-55$ & 5 & 2.6 \\
Qualification & $56-60$ & 3 & 1.6 \\
& Matric & 17 & 8.8 \\
& Intermediate & 112 & 58.4 \\
& Graduation & 47 & 24.5 \\
\hline
\end{tabular}

The data was gathered from staffs working in different departments and divisions of textile industries in Faisalabad. Percentage of data was 40.7 between 18-25 years, the percentage of data was 35.9 between $26-35$ years, the percentage of data was 16.1 between $36-45$ years, the percentage of data was 3.1between 46-50 years, the percentage of data was2.6 between 51-55 years and percentage of data was 1.6 between 56-60 years old. The qualification of Matric participants was 8.8 percent, 58.4 percent of Intermediate, 24.5 percent of Graduation and 8.3 percent of Master.

\section{CORRELATION}

The analysis of correlation relations was used to find the relationship between every variable in this model. The test presented that correlation is significant at the level of 0.01 and 0.05 that is adapted to find the link between the independent and dependent variable. It showed the relationship is positive between POS, PCB and TI with the correlation of $0.732,0.823$ and 0.791 which is highly correlated because it is greater than zero and nearly 1.

\section{Table 2}

\section{Correlation of variables}

\begin{tabular}{llllll}
\hline & variables & Alpha & POS & PCB & TI \\
\hline 1 & POS & 0.732 & 1 & & \\
2 & PCB & 0.823 & $.688^{* *}$ & 1 & \\
3 & TI & 0.791 & $.725^{* *}$ & $.638^{* *}$ & 1 \\
\hline
\end{tabular}

**. Correlation is significant at the $0.01 * *$

POS= Perceived Organizational Support

$\mathrm{PCB}=$ Psychological Contract Breach

$\mathrm{TI}=$ Turnover Intention 
INTERNATIONAL JOURNAL OF ACADEMIC RESEARCH IN BUSINESS AND SOCIAL SCIENCES

Vol. 8, No. 9, Sept. 2018, E-ISSN: 2222-6990 (C) 2018 HRMARS

\section{REGRESSION}

The above table showed the relationship between the independent and dependent variable. The regression of multiple linear was the help to check the coefficient which used to analyze the link between the independent and dependent variable. The above table presented that Perceived Organizational Support R-value is 0.390 and R square 0.386, ß value 0.390, SE value 0. 50153 and Psychological Contract Breach R-value 0.454, $R$ square value $0.402, \beta$ value 0.236 and SE value 0 . 48738.

Model Summary

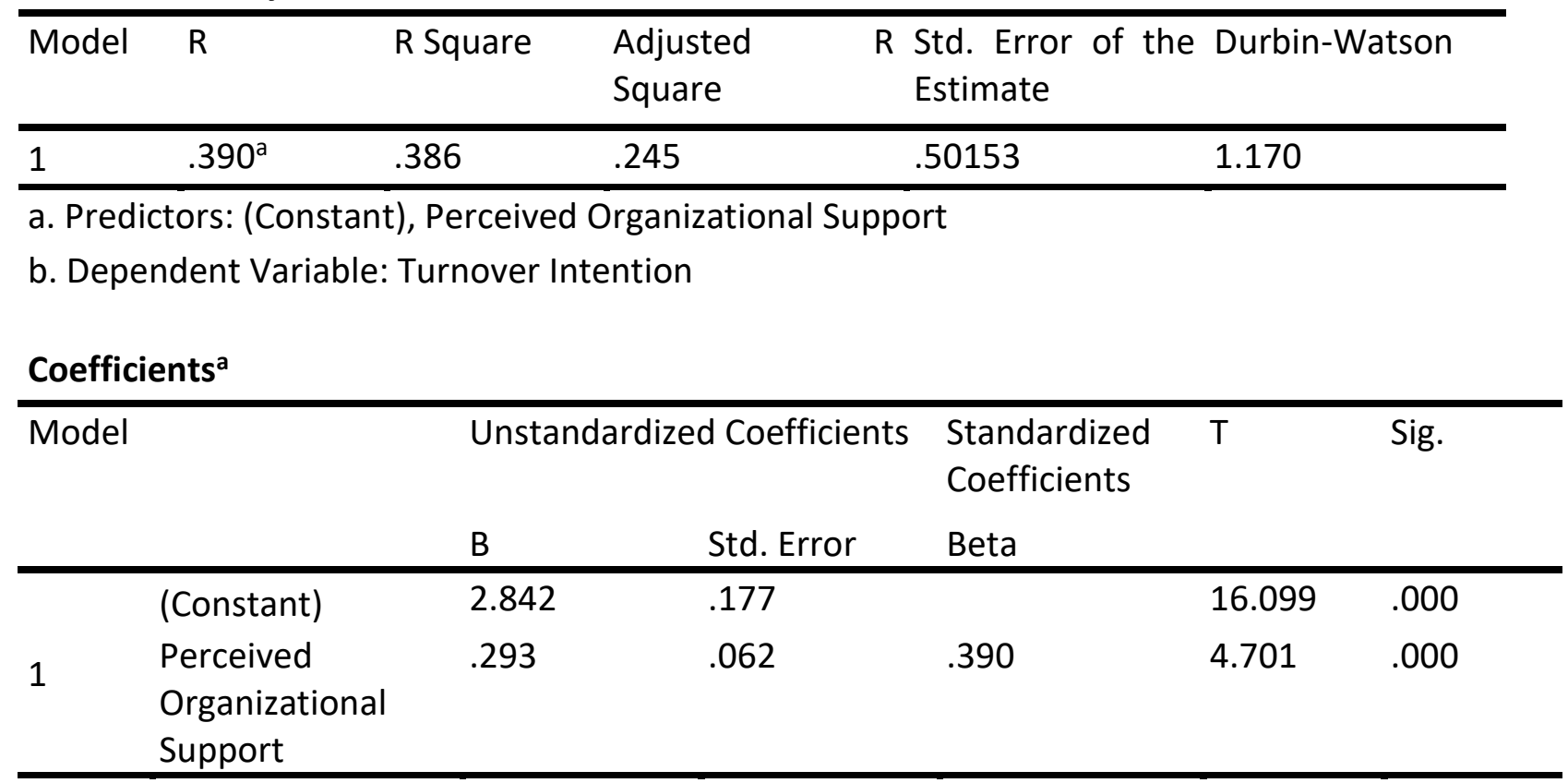

a. Dependent Variable: Turnover Intention

Model Summaryc

\begin{tabular}{llllll}
\hline Model & $\mathrm{R}$ & R Square & Adjusted R Square & $\begin{array}{l}\text { Std. Error of the Durbin-Watson } \\
\text { Estimate }\end{array}$ \\
\hline 1 & $.390^{\mathrm{a}}$ & .386 & .245 & .50153 & \\
2 & $.454^{\mathrm{b}}$ & .402 & .293 & .48738 & 1.248 \\
\hline
\end{tabular}

a. Predictors: (Constant), Perceived Organizational Support

b. Predictors: (Constant), Perceived Organizational Support, Psychological Contract Breach

c. Dependent Variable: Turnover Intention 
INTERNATIONAL JOURNAL OF ACADEMIC RESEARCH IN BUSINESS AND SOCIAL SCIENCES Vol. 8, No. 9, Sept. 2018, E-ISSN: 2222-6990 @ 2018 HRMARS

\begin{tabular}{|c|c|c|c|c|c|c|}
\hline \multirow[t]{2}{*}{ Model } & & \multicolumn{2}{|c|}{ Unstandardized Coefficients } & \multirow{2}{*}{$\begin{array}{l}\text { Standardized } \\
\text { Coefficients } \\
\text { Beta }\end{array}$} & \multirow[t]{2}{*}{$\mathrm{T}$} & \multirow[t]{2}{*}{ Sig. } \\
\hline & & B & Std. Error & & & \\
\hline \multirow[b]{2}{*}{1} & (Constant) & 2.842 & .177 & & 16.099 & .000 \\
\hline & $\begin{array}{l}\text { Perceived } \\
\text { Organizational Support }\end{array}$ & .293 & .062 & .390 & 4.701 & .000 \\
\hline \multirow{3}{*}{2} & (Constant) & 2.915 & .206 & & 12.211 & .000 \\
\hline & $\begin{array}{l}\text { Perceived } \\
\text { Organizational Support }\end{array}$ & .261 & .062 & .348 & 4.241 & .000 \\
\hline & $\begin{array}{l}\text { Psychological Contract } \\
\text { Breach }\end{array}$ & .144 & .050 & .236 & 2.871 & .000 \\
\hline
\end{tabular}

a. Dependent Variable: Turnover Intention

\section{RECOMMENDATIONS}

There are some recommendations for the organization to overcome turnover intention. Training system should be proper on work behaviour and attitudes for managers so they can avoid negative attitude or behaviour towards their employees. The organization must apply the reward system so employees can be motivated. Moreover, lack of training of employees can cause for employees to leave the organization. So the organization should be implementing the proper training system for employees.

\section{CONCLUSIONS}

After conducting this research showed that job dissatisfaction causes the employee turnover. There are many factors of dissatisfaction like the negative behaviour of the employer towards the employee, toxic culture of the organization, no career opportunity and not enough motivation system. So, it needs to be for the organization to overcome these issues to control the turnover. The organization should care about the satisfaction of employees because due to job satisfaction employees are willing to stay in the organization.

\section{FUTURE RESEARCH}

The research is quantitative and has many limitations, so it is recommended that taking the qualitative study so that to more depth approach about the organization. The sample size was 192 which are very small. To get the reliable results sample size can increase. Moreover, data was collected only textile sector of Faisalabad city, so the researchers can increase the scope of organizations to get the more valid result. 
INTERNATIONAL JOURNAL OF ACADEMIC RESEARCH IN BUSINESS AND SOCIAL SCIENCES

Vol. 8, No. 9, Sept. 2018, E-ISSN: 2222-6990 @ 2018 HRMARS

Muhammad Zubair Shafique (Corresponding Author)

MS Scholar (Department Public Administration)

Government College University, Faisalabad Pakistan

Email: zubairshafique5@gmail.com

\section{REFERENCES}

Aliyu, O. A., \& Nyadzayo, M. W. (2018). Reducing employee turnover intention: a customer relationship management perspective. Journal of Strategic Marketing, 26(3), 241-257.

Ashar, M., Ghafoor, M., Munir, E., \& Hafeez, S. (2013). The impact of perceptions of training on employee commitment and turnover intention: Evidence from Pakistan. International journal of human resource studies, 3(1), 74-88.

Caesens, G., Marique, G., Hanin, D., \& Stinglhamber, F. (2016). The relationship between perceived organizational support and proactive behaviour directed towards the organization. European Journal of Work and Organizational Psychology, 25(3), 398-411.

Chan, S. H., Chok, S. Y., Lae, S. Y., Lam, A. C., \& Lee, C. Y. (2017). The Impact of Perceived Organizational Support, Job Satisfaction, Leader-Member Exchange (LMX) and Work-Life Balance On Employee's Turnover Intention in Manufacturing Industry, Malaysia. UTAR.

Chen, Y., Kim, Y.-K., Liu, Z., Wang, G., \& Zhao, G. (2018). Can HPWS and Unions Work Together to Reduce Employee Turnover Intention in Foreign MNCs in China? Advances in Industrial and Labor Relations, 2017: Shifts in Workplace Voice, Justice, Negotiation and Conflict Resolution in Contemporary Workplaces (pp. 213-242): Emerald Publishing Limited.

Colakoglu, U., Culha, O., \& Atay, H. (2010). The effects of perceived organisational support on employees' affective outcomes: evidence from the hotel industry. Tourism and hospitality management, 16(2), 125-150.

Cummann, C., Fichman, M., Jenkins, D., \& Klesh, J. (1979). The Michigan Organisational Assessment Questionnaire, University of Michigan. Ann Arbor, MI.

Egan, T. M., Yang, B., \& Bartlett, K. R. (2004). The effects of organizational learning culture and job satisfaction on motivation to transfer learning and turnover intention. Human resource development quarterly, 15(3), 279-301.

Eisenberger, R., Huntington, R., Hutchison, S., \& Sowa, D. (1986). Perceived organizational support. Journal of applied psychology, 71(3), 500.

Farooqui, M. R., \& Ahmed, M. (2013). Why Workers Switch Industry? The Case of Textile Industry of Pakistan. Asian Journal of Business Management, 5(1), 130-139.

Gakovic, A., \& Tetrick, L. E. (2003). Psychological contract breach as a source of strain for employees. Journal of business and psychology, 18(2), 235-246.

Gupta, V., Agarwal, U. A., \& Khatri, N. (2016). The relationships between perceived organizational support, affective commitment, psychological contract breach, organizational citizenship behaviour and work engagement. Journal of advanced nursing, 72(11), 2806-2817.

Gyensare, M. A., Anku-Tsede, O., Sanda, M.-A., \& Okpoti, C. A. (2016). Transformational leadership and employee turnover intention: The mediating role of affective commitment. World Journal of Entrepreneurship, Management and Sustainable Development, 12(3), 243-266. 
INTERNATIONAL JOURNAL OF ACADEMIC RESEARCH IN BUSINESS AND SOCIAL SCIENCES

Vol. 8, No. 9, Sept. 2018, E-ISSN: 2222-6990 @ 2018 HRMARS

Hussain, T., \& Asif, S. (2012). Is employees' turnover intention driven by organizational commitment and perceived organizational support. Journal of quality and technology management, 8(2), 1-10.

Iqbal, S., Ehsan, S., Rizwan, M., \& Noreen, M. (2014). The impact of organizational commitment, job satisfaction, job stress and leadership support on turnover intention in educational institutes. International journal of human resource studies, 4(2), 181-195.

Jaramillo, F., Mulki, J. P., \& Solomon, P. (2006). The role of ethical climate on salesperson's role stress, job attitudes, turnover intention, and job performance. Journal of Personal Selling \& Sales Management, 26(3), 271-282.

Johnson, J. L., \& O'Leary-Kelly, A. M. (2003). The effects of psychological contract breach and organizational cynicism: Not all social exchange violations are created equal. Journal of Organizational Behavior: The International Journal of Industrial, Occupational and Organizational Psychology and Behavior, 24(5), 627-647.

Khoo, H. Y., Chan, S. L., Leong, C. F., Ng, K. M., \& Siam, W. C. (2017). High Performance Work System (HPWS) and Turnover Intention in Malaysia Retail Industry. UTAR.

Kickul, J., \& Lester, S. W. (2001). Broken promises: Equity sensitivity as a moderator between psychological contract breach and employee attitudes and behavior. Journal of business and psychology, 16(2), 191-217.

Kim, K. Y., Eisenberger, R., \& Baik, K. (2016). Perceived organizational support and affective organizational commitment: Moderating influence of perceived organizational competence. Journal of Organizational Behavior, 37(4), 558-583.

Kim, W., \& Hyun, Y. S. (2017). The impact of personal resources on turnover intention: The mediating effects of work engagement. European Journal of Training and Development, 41(8), 705-721.

Kurtessis, J. N., Eisenberger, R., Ford, M. T., Buffardi, L. C., Stewart, K. A., \& Adis, C. S. (2015). Perceived Organizational Support: A Meta-Analytic Evaluation of Organizational Support Theory.

Lee, S. H., \& Ha-Brookshire, J. (2017). Ethical climate and job attitude in fashion retail employees' turnover intention, and perceived organizational sustainability performance: A crosssectional study. Sustainability, 9(3), 465.

Lester, S. W., Turnley, W. H., Bloodgood, J. M., \& Bolino, M. C. (2002). Not seeing eye to eye: Differences in supervisor and subordinate perceptions of and attributions for psychological contract breach. Journal of Organizational Behavior, 23(1), 39-56.

Makhdoom, T. R. (2018). Analyzing The Factors Affecting Employees' Turnover In Textile Mills Of Site Area Kotri, Sindh (Pakistan). Grassroots, 51(2).

Manchester, C. F. (2010). Investment in General Human Capital and Turnover Intention. The American Economic Review, 100(2), 209-213.

Memon, M. A., Sallaeh, R., Baharom, M. N. R., Md Nordin, S., \& Ting, H. (2017). The relationship between training satisfaction, organisational citizenship behaviour, and turnover intention: $A$ PLS-SEM approach. Journal of Organizational Effectiveness: People and Performance, 4(3), 267-290.

Nawaz, Y., \& Siraji, M. (2009). Role of Voluntary Employee Turnover in Textile Industry of Pakistan. 
INTERNATIONAL JOURNAL OF ACADEMIC RESEARCH IN BUSINESS AND SOCIAL SCIENCES

Vol. 8, No. 9, Sept. 2018, E-ISSN: 2222-6990 @ 2018 HRMARS

Nie, D., Lämsä, A. M., \& Pučètaitè, R. (2018). Effects of responsible human resource management practices on female employees' turnover intentions. Business Ethics: A European Review, 27(1), 29-41.

Noor, S., \& Maad, N. (2009). Examining the relationship between work life conflict, stress and turnover intentions among marketing executives in Pakistan. International journal of Business and Management, 3(11), 93.

Ongori, H. (2007). A review of the literature on employee turnover.

Poon, J. M. (2004). Effects of performance appraisal politics on job satisfaction and turnover intention. Personnel review, 33(3), 322-334.

Qureshi, M. I., Iftikhar, M., Abbas, S. G., Hassan, U., Khan, K., \& Zaman, K. (2013). Relationship between job stress, workload, environment and employees turnover intentions: What we know, what should we know. World Applied Sciences Journal, 23(6), 764-770.

Rahman, A., Naqvi, S., \& Ramay, M. I. (2008). Measuring turnover intention: A study of it professionals in Pakistan. International Review of Business Research Papers, 4(3), 45-55.

Rhoades, L., \& Eisenberger, R. (2002). Perceived organizational support: a review of the literature. Journal of applied psychology, 87(4), 698.

Riaz, H., Akhtar, N., Moazzam, A., Luqman, R., Naz, H., \& Tufail, H. S. (2017). Leadership Effectiveness, Turnover Intention and the Mediating Role of Employee Commitment: A Case of Academic Institutions of Pakistan. European Online Journal of Natural and Social Sciences, 6(4), pp. 526534.

Richer, S. F., Blanchard, C., \& Vallerand, R. J. (2002). A motivational model of work turnover. Journal of Applied Social Psychology, 32(10), 2089-2113.

Robinson, S. L. (1996). Trust and breach of the psychological contract. Administrative science quarterly, 574-599.

Robinson, S. L., \& Rousseau, D. M. (1994). Violating the psychological contract: Not the exception but the norm. Journal of Organizational Behavior, 15(3), 245-259.

Rousseau, D. (1995). Psychological contracts in organizations: Understanding written and unwritten agreements: Sage Publications.

Tanova, C., \& Holtom, B. C. (2008). Using job embeddedness factors to explain voluntary turnover in four European countries. The International Journal of Human Resource Management, 19(9), 1553-1568.

Yuan, L., Yu, Y., Li, J., \& Ning, L. (2014). Occupational commitment, industrial relations and turnover intention: Empirical evidence from China. Chinese Management Studies, 8(1), 66-84. 